\title{
Airway epithelial inflammatory responses and clinical parameters in COPD
}

\author{
I.S. Patel, N.J. Roberts, S.J. Lloyd-Owen, R.J. Sapsford, J.A. Wedzicha
}

Airway epithelial inflammatory responses and clinical parameters in COPD. I.S. Patel, N.J. Roberts, S.J. Lloyd-Owen, R.J. Sapsford, J.A. Wedzicha. (C) ERS Journals Ltd 2003.

ABSTRACT: This study examined inflammatory responses from primary cultured human bronchial epithelial cells in chronic obstructive pulmonary disease (COPD) and the clinical factors modulating them.

Epithelial cells from bronchoscopic biopsies from 14 patients with COPD ((mean \pm SD) age 74.6 $\pm 5.7 \mathrm{yrs,}$, forced expiratory volume in one second (FEV1) $1.21 \pm 0.36 \mathrm{~L}$, FEV $1 \%$ predicted $51.1 \pm 15.8 \%, 51.5 \pm 24.0$ pack-yrs of smoking, inhaled steroid dosage 1237.5 $\pm 671.0 \mu \mathrm{g} \cdot \mathrm{day}^{-1}$, Medical Research Council (MRC) dyspnoea score $3.18 \pm 1.33$ ) and eight current/exsmokers with normal pulmonary function (age 60.4 \pm 13.5 yrs, FEV1 2.66 $\pm 1.27 \mathrm{~L}$, FEV1 \% pred 89.6 $\pm 17.7 \%, 49 \pm 44$ pack-yrs of smoking, MRC dyspnoea score 1 \pm 0 ) were grown in primary culture and exposed to $50 \mathrm{ng} \cdot \mathrm{mL}^{-1}$ tumour necrosis factor- $\alpha$.

Stimulated COPD cells produced significantly more interleukin (IL)-6 at 24 and $48 \mathrm{~h}$, and IL-8 at 6 and $24 \mathrm{~h}$ than unstimulated COPD cells. This response was not seen in cells from current/exsmokers. IL-6 and IL-8 production was lower in COPD patients taking inhaled steroids.

Following an inflammatory stimulus, bronchial epithelial cells in chronic obstructive pulmonary disease show a significant cytokine response not seen in smokers with normal pulmonary function and this may be modified by inhaled steroid therapy.

Eur Respir J 2003; 22: 94-99.
Academic Unit of Respiratory Medicine, St Bartholomew's and the Royal London Hospital School of Medicine and Dentistry, London, UK.

Correspondence: J.A. Wedzicha, Academic Unit of Respiratory Medicine, Dominion House, St Bartholomew's Hospital, West Smithfield, London EC1A 7BE, UK.

Fax: 442076018616

E-mail: j.a.wedzicha@qmul.ac.uk

Keywords: Airway

chronic obstructive pulmonary disease corticosteroids

epithelium

inflammation

Received: October 142002

Accepted after revision: March 112003

This study was supported by the Joint Research Board, St Bartholomew's Hospital, London, UK.
Patients with chronic obstructive pulmonary disease (COPD) exhibit heightened airway inflammation, characterised by increased levels of interleukin (IL)-8 and tumour necrosis factor (TNF)- $\alpha$ in induced sputum [1], a predominantly neutrophilic cellular infiltrate in the airway lumen [2], and increased lymphocyte numbers in the submucosa and alveolar parenchyma [3]. They are prone to exacerbations, which are a major cause of hospital admission [4] and an important determinant of health-related quality of life [5]. It has been demonstrated that stable patients with a history of frequent exacerbations have increased induced sputum levels of IL-6 and IL-8, and that sputum levels of IL-6 further increase at COPD exacerbation [6]. This suggests that COPD may be associated with enhanced airway epithelial cell activation, particularly at exacerbation, though the mechanisms underlying this are largely unknown.

There is increasing evidence that as well as acting as an important physicochemical barrier protecting the submucosa, the airway epithelium is a metabolically active mediator in the pathophysiology of respiratory disease [7, 8]. Bronchial epithelial cells synthesise and release a number of proinflammatory factors both constitutively and in response to external stimuli [9], thereby influencing inflammatory cell chemotaxis, recruitment, activation and differentiation [10]. However, the role of the bronchial epithelium in modulating inflammatory processes in COPD, either under stable conditions or at exacerbation, has not been identified.

This study was designed to evaluate the response made by primary-cultured human bronchial epithelial cells (HBEC) from patients with COPD to an inflammatory stimulus. TNF$\alpha$ is a pro-inflammatory cytokine present in the COPD airway [11], which stimulates cytokine release by epithelial cells [12]. Stimulation with TNF- $\alpha$ was therefore used as a model for what may occur, in part, at the epithelial level during COPD exacerbations. In addition, factors modulating epithelial inflammatory responses in COPD were examined, including physiological parameters and inhaled steroid therapy.

\section{Materials and methods}

\section{Study subjects}

Volunteers $(n=22)$ were prospectively recruited to the study from those patients undergoing routine clinically indicated bronchoscopy at the London Chest Hospital, UK. Fourteen patients with COPD and eight current or exsmokers with normal pulmonary function were sampled. COPD was defined as a forced expiratory volume in one second (FEV1) $<70 \%$ predicted for age and height, $\beta_{2}$-agonist reversibility on predicted FEV1 of $<15 \%$ and/or $200 \mathrm{~mL}$ with airflow obstruction as evidenced by an FEV1/forced vital capacity (FVC) ratio of $<70 \%$. Patients were excluded from the study if they had active respiratory tract infections, including ongoing or recent exacerbations of COPD, suspected tuberculosis, bronchiectasis or asthma. Before the procedure, a detailed history was taken from each study subject outlining their 
Table 1.-Physiological characteristics of study subjects

\begin{tabular}{lcc}
\hline & COPD patients & Normal subjects \\
\hline Subjects n & 14 & 8 \\
Age yrs & $74.6 \pm 5.7$ & $60.4 \pm 13.5$ \\
FEV1 L & $1.20 \pm 0.36$ & $2.66 \pm 1.27$ \\
FEV1 \% pred & $51.1 \pm 15.8$ & $89.6 \pm 17.7$ \\
FVC L & $2.70 \pm 0.75$ & $3.72 \pm 1.66$ \\
FEV1/FVC & $47.4 \pm 13.4$ & $78.4 \pm 7.5$ \\
$P a, \mathrm{O}_{2} \mathrm{kPa}$ & $8.80 \pm 1.82$ & $9.96 \pm 0.72$ \\
$P a, \mathrm{CO}_{2} \mathrm{kPa}$ & $5.20 \pm 0.57$ & $5.32 \pm 0.66$ \\
Pack-yrs of smoking & $51.5 \pm 24.0$ & $49.0 \pm 44.0$ \\
MRC dyspnoea score & $3.20 \pm 1.33$ & $1.00 \pm 0.00$ \\
Current smokers & 8 & 6 \\
\hline
\end{tabular}

Data are presented as mean \pm SD unless otherwise stated. COPD: chronic obstructive pulmonary disease; FEV1: forced expiratory volume in one second; $\%$ pred: $\%$ predicted; FVC: forced vital capacity; $\mathrm{Pa}, \mathrm{O}_{2}$ : arterial oxygen tension; $\mathrm{Pa}, \mathrm{CO}_{2}$ : arterial carbon dioxide tension; MRC: Medical Research Council.

smoking habits (current smoking status, years of smoking and number of packs of 20 cigarettes smoked per day), drug history including inhaled steroid dosage, daily stable respiratory symptoms and Medical Research Council dyspnoea score. Baseline spirometry, and, where possible, arterialised capillary earlobe blood gases [13] were also obtained prior to the planned procedure.

Table 1 shows the physiological characteristics of the study subjects. The COPD patients were older than the normal subjects $(\mathrm{p}<0.05)$. The two groups were matched for pack-yrs of smoking $(\mathrm{p}=0.15)$, however, eight $(51.7 \%)$ of the COPD patients and six $(75 \%)$ of the normal subjects were current smokers. Within the COPD group, eight $(51.7 \%)$ patients were taking regular inhaled steroids at a mean \pm SD dose of $1,237.5 \pm 671 \mu \mathrm{g} \cdot \mathrm{day}^{-1}$. Within the current/exsmokers with normal pulmonary function, two $(25 \%)$ patients had a final diagnosis of bronchial carcinoma and one $(12.5 \%)$ was found to have a mesothelioma. None of the patients with COPD had bronchial carcinoma and none of the subjects were taking any medications (other than inhaled steroids) that may have affected their airway inflammatory responses.

Each volunteer underwent fibreoptic bronchoscopy under light sedation and local anaesthesia according to the British Thoracic Society guidelines [14]. Endobronchial biopsies were taken using rotatable cup-biopsy forceps (Olympus FB19KR; KeyMed Ltd, Southend-on-Sea, UK) at the level of a segmental or subsegmental carina on the side opposite to any radiological abnormality precipitating the bronchoscopy. Biopsies were immediately placed in ice-cold medium 199 (Sigma-Aldrich Co Ltd, Poole, UK) containing 1\% gentamicin (Roussel Laboratories Ltd, Uxbridge, UK) and processed for tissue culture within $30 \mathrm{~min}$.

The Ethics Committee of the East London and City Health Authority granted full approval for this study and fully informed written consent was obtained from all participants prior to their inclusion.

\section{Materials}

All reagents and chemicals were of tissue culture grade and provided by the Sigma-Aldrich Co Ltd unless otherwise stated. All prepared solutions were filtered through a $0.20 \mu \mathrm{m}$ pore Minisart syringe filter (Sartorius Ltd, Epsom, UK) before addition to the cell cultures.

\section{Culture of bronchial epithelial cells}

HBEC were grown in primary culture using the explant cell culture technique developed in the laboratory. The epithelium was dissected away from any underlying lamina propria, cut into smaller sections $\sim 0.5 \mathrm{~mm}^{3}$ in size and washed three times with sterile medium 199. Single sections of epithelium were then explanted onto 6-cm Falcon Primeria plastic culture dishes (Becton Dickinson Ltd, Oxford, UK) and incubated with $1.5 \mathrm{~mL}$ of complete culture medium at $37^{\circ} \mathrm{C}$ in a humidified $5 \%$ carbon dioxide air atmosphere. The culture medium was prepared by mixing $250 \mu \mathrm{g}$ bovine pancreatic insulin, $250 \mu \mathrm{g}$ of human transferrin, $1.5 \mathrm{~mL}$ of antibiotic/ antimycotic solution, $3 \mathrm{mg}$ L-glutamine and $2.5 \mathrm{~mL} \mathrm{NU}$ serum (Universal Biologicals Ltd, Gloucestershire, UK) in $100 \mathrm{~mL}$ of medium 199. The medium in each dish was replaced with maintenance medium after 7 days and every $48 \mathrm{~h}$ thereafter.

\section{Exposure of human bronchial epithelial cells to TNF- $\alpha$}

The cultures were observed until the cells had grown to confluence after 3-4 weeks. On the day prior to the experiment, explants were removed and cultures were washed, and incubated overnight in medium 199 and an antibiotic/antimycotic solution for $24 \mathrm{~h}$. HBEC cultures were then washed twice with $2 \mathrm{~mL}$ of sterile medium 199 before the addition of the appropriate reagents. In the case of TNF$\alpha$-exposed dishes, this consisted of $2.5 \mathrm{~mL}$ of a $50 \mathrm{ng} \cdot \mathrm{mL}^{-1}$ solution of recombinant TNF- $\alpha$ (R\&D Systems Europe, Abingdon, UK) made up in medium 199 and antibiotic/ antimycotic solution. This concentration of TNF- $\alpha$ had been determined not from physiological measurements, but using preliminary exposure experiments in the laboratory showing inadequate stimulation at $25 \mathrm{ng} \cdot \mathrm{mL}^{-1}$ but cell death with reduced cell product at $100 \mathrm{ng} \cdot \mathrm{mL}^{-1}$ [15]. The unstimulated dishes were incubated with $2.5 \mathrm{~mL}$ of medium 199 and antibiotic/antimycotic solution only. An aliquot of supernatant was collected from culture dishes immediately after the addition of either TNF- $\alpha$ or control solution (time zero). Cells were then incubated as before, and aliquots of supernatant were collected at 6,24 and $48 \mathrm{~h}$. All samples were stored at $-70^{\circ} \mathrm{C}$ for cytokine analysis using quantitative sandwich immunoassay techniques (R\&D Systems Europe). IL-6, IL-8 and soluble intercellular adhesion molecule (sICAM)-1 levels were measured in the cell supernatant. Experiments were terminated at $48 \mathrm{~h}$, at which time cells were stored at $-70^{\circ} \mathrm{C}$ for total cellular protein analysis as described by LOWRY et al. [16].

\section{Analysis}

Cytokine release from HBEC was measured in absolute values of $\mathrm{pg} \cdot \mu \mathrm{g}$ cellular protein $^{-1}$ at each time point. To allow for differences in baseline cytokine production, the percentage change in cytokine production from time zero was calculated for times $0-6,0-24$ and $0-48 \mathrm{~h}$ for each experimental group. Normally distributed data were summarised by mean \pm SD and skewed data by medians (interquartile range (IQR)). Continuous variables with normal distributions were compared by an unpaired t-test, whereas those with non-normal distributions were compared by the Mann-Whitney U-test or Wilcoxon signed-rank test, as appropriate. Cytokine levels, and physiological and other indices were correlated using Spearman's rank correlation. 


\section{Results}

Culture and identification of human bronchial epithelial cells

The identity of the epithelial cells was confirmed in all cultures by light microscopy, demonstrating large numbers of cells with polygonal morphology. In randomly selected cultures, electron microscopy and immunocytochemical staining for cytokeratin were performed using monoclonal antibody preparation CAM 5.2 (Becton Dickinson Ltd) to confirm the epithelial nature of the cells. Only cultures demonstrating $\geqslant 50 \%$ ciliated cells, with good ciliary motility, were used in experiments, and no qualitative differences in the degree of cilliation or differentiation were seen in this study between COPD cells and those from subjects with normal lung function. Staining with specific monoclonal antibodies against contaminating cell types, such as fibroblasts, did not show any evidence of these cells.

Cytokine production by human bronchial epithelial cells in the absence of TNF- $\alpha$ stimulation

sICAM-1 production by COPD HBEC under baseline conditions was lower in the presence of inhaled steroid therapy (rho $=-0.732, \mathrm{p}=0.039$ for sICAM-1 at $24 \mathrm{~h}$ ). No relationships were seen in normal HBECs between baseline cytokine production and any of the physiological or clinical parameters outlined above.

\section{Cytokine response to $T N F-\alpha$ stimulation: $C O P D$ versus currentlexsmoker cell cultures}

Table 2 shows the median (IQR) levels of IL-6, IL-8 and sICAM-1 production at each time point from unstimulated cells and cells exposed to TNF- $\alpha$ within the smokers/ exsmokers without airways obstruction, and cells from COPD patients. The absolute level of cytokine production was greater from cells from current/exsmokers than from COPD cells at each time point, irrespective of stimulation with TNF- $\alpha$. However, within the current/exsmokers there was no statistically significant response to TNF- $\alpha$, as measured by an increase in cytokine production by HBEC over baseline values. Within the COPD group, TNF$\alpha$-exposed HBEC produced significantly greater amounts of IL-6 at $6(\mathrm{p}=0.053), 24(\mathrm{p}=0.006)$ and $48 \mathrm{~h} \quad(\mathrm{p}=0.015)$ compared with unstimulated cells (fig. 1a). Similarly, IL-8 production was greater at $6(\mathrm{p}=0.025)$ and $24 \mathrm{~h}(\mathrm{p}=0.045)$ in the stimulated group in contrast to unstimulated cells (fig. 1b). A trend towards increased sICAM-1 production in the TNF- $\alpha$-exposed COPD cells was seen at $48 \mathrm{~h}(\mathrm{p}=0.08$; fig. $1 \mathrm{c}$ ).

When the percentage changes in cytokine production from time zero were calculated, a significant increase in sICAM-1 production in response to TNF- $\alpha$ was seen in the COPD group at $48 \mathrm{~h}(\mathrm{p}=0.014)$.

Effect of inhaled steroid therapy on cytokine production from stimulated COPD human bronchial epithelial cells

Figure 2 shows IL-6 and IL-8 production from stimulated COPD cell cultures in the presence and absence of regular, inhaled steroid therapy. Median (IQR) IL-6 production at $48 \mathrm{~h}$ in the steroid-free group was $0.98(1.35)$ in contrast to $0.72(0.21) \mathrm{pg} \cdot \mu \mathrm{g}$ cellular protein ${ }^{-1}$ in those on inhaled steroids $(\mathrm{p}=0.03)$. IL-6 production was negatively correlated with inhaled steroid dosage at all time points (time $0-6 \mathrm{~h}$ : rho $=-0.849, \mathrm{p}=0.016 ; 0-24 \mathrm{~h}: \mathrm{rho}=-0.926, \mathrm{p}=0.003 ; 0-48 \mathrm{~h}$ : rho $=-0.949, \mathrm{p}=0.05)$. IL-8 production at $24 \mathrm{~h}$ was $30.0(17.1)$ in the steroid-free group and $19.50(7.75) \mathrm{pg} \cdot \mu \mathrm{g}$ protein $^{-1}$ in the steroid-treated group $(\mathrm{p}=0.03)$. At $48 \mathrm{~h}$, IL-8 production was $33.6(23.4)$ and $21.7(6.3) \mathrm{pg} \cdot \mu \mathrm{g}$ protein ${ }^{-1}$, respectively $(\mathrm{p}=0.05)$. No direct relationship was seen between IL-8 levels and inhaled steroid dosage. Inhaled steroids did not affect sICAM-1 production at any time point after stimulation.

Inhaled steroid therapy was related to spirometric criteria; the mean \pm SD FEV1 in patients taking inhaled steroids was $0.98 \pm 0.08$ in contrast to $1.50 \pm 0.41 \mathrm{~L}$ in those not taking them $(\mathrm{p}=0.027)$. Similarly the mean FEV1 \% pred in the steroidtreated group was $40.0 \pm 9.4$ in contrast to 66 (2.9) in the steroid-free group $(\mathrm{p}<0.001)$, and the mean $\mathrm{FEV} 1 / \mathrm{FVC}$ ratio was $38(9.5)$ and $61(7.5)(\mathrm{p}<0.001)$ in the two groups, respectively.

\section{Discussion}

This study examined the inflammatory responses made by primary-cultured bronchial epithelial cells in COPD, and the clinical and physiological factors modulating these in a wellcharacterised group of patients. Compared with current/ exsmokers without airways obstruction, epithelial cells from patients with COPD were found to release lower levels of IL6, IL-8 and sICAM-1 under baseline conditions, but mounted a significant cytokine response to TNF- $\alpha$, which was not seen in cells from normal smokers. Within the COPD group, the

Table 2. - Interleukin (IL)-6, IL-8 and soluble intercellular adhesion molecule (sICAM)-1 production

\begin{tabular}{|c|c|c|c|c|c|c|c|}
\hline & \multirow[t]{2}{*}{ Time h } & \multicolumn{3}{|c|}{ Normal smokers/exsmokers } & \multicolumn{3}{|c|}{ COPD } \\
\hline & & Unstimulated & TNF- $\alpha$ exposed & p-value & Unstimulated & TNF- $\alpha$ exposed & p-value \\
\hline \multirow[t]{3}{*}{ IL-6 } & 6 & $1.5(2.46)$ & $1.21(2.53)$ & 0.81 & $0.08(0.29)$ & $0.33(0.41)$ & 0.05 \\
\hline & 24 & $2.24(3.4)$ & $2.63(2.89)$ & 0.68 & $0.31(0.45)$ & $0.71(0.42)$ & 0.006 \\
\hline & 48 & $2.8(3.95)$ & $3.2(3.02)$ & 0.91 & $0.44(0.54)$ & $0.82(0.56)$ & 0.015 \\
\hline \multirow[t]{3}{*}{ IL-8 } & 6 & $19.8(10.7)$ & $25.3(6.92)$ & 0.37 & $6.25(7.05)$ & $12.6(9.05)$ & 0.025 \\
\hline & 24 & $32.6(13.5)$ & $35.7(11.5)$ & 0.57 & $12.0(10.5)$ & $21.9(15.6)$ & 0.045 \\
\hline & 48 & $36.1(35.6)$ & $35.6(19.1)$ & 0.78 & $14.5(12.4)$ & $23.5(17.6)$ & 0.21 \\
\hline \multirow[t]{3}{*}{ sICAM-1 } & 6 & $11.7(4.8)$ & $9.45(4.07)$ & 0.8 & $5.6(3.0)$ & $6.5(2.63)$ & 0.37 \\
\hline & 24 & $23.7(9.2)$ & $30.5(13.2)$ & 0.028 & $10.3(8.4)$ & $14.8(31.7)$ & 0.5 \\
\hline & 48 & $43.3(21.1)$ & $56.1(48.6)$ & 0.76 & $15.6(4.8)$ & $25.2(22.3)$ & 0.08 \\
\hline
\end{tabular}

Data are presented as median (interquartile range). Levels ( $\mathrm{pg} \cdot \mu \mathrm{g}$ cellular protein ${ }^{-1}$ ) of IL-6, IL-8 and sICAM-1 were recorded at 6 , 24 and $48 \mathrm{~h}$ from unstimulated cells and those exposed to tumour necrosis factor (TNF)- $\alpha$, within the smokers/exsmokers without airways obstruction and patients with chronic obstructive pulmonary disease (COPD). 

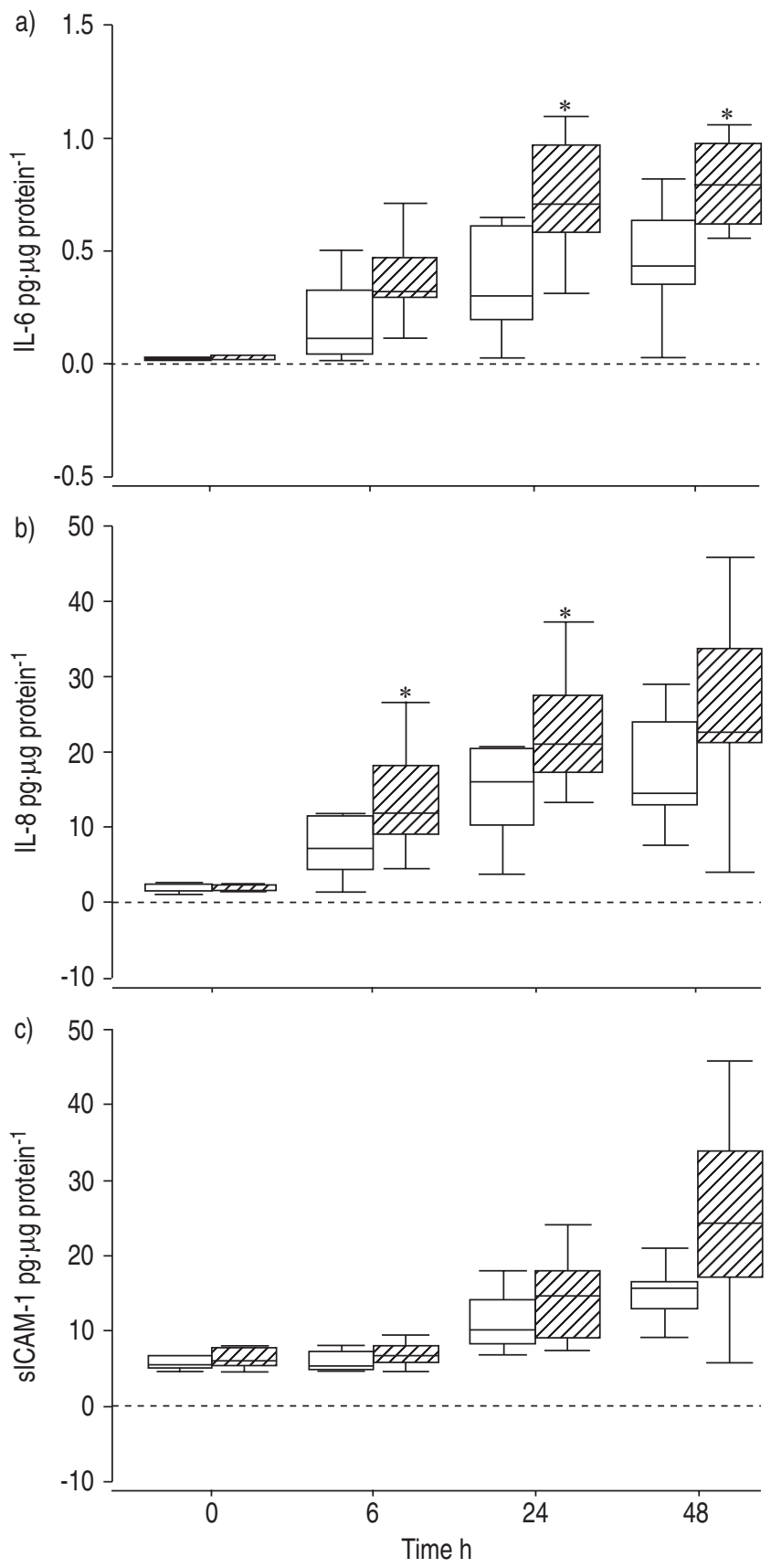

Fig. 1.-Production of a) interleukin (IL)-6, b) IL-8 and c) soluble intercellular adhesion molecule (sICAM)-1 by control ( $\square$ ) and tumour necrosis factor (TNF)- $\alpha$-stimulated (ש্Z), primary-cultured chronic obstructive pulmonary disease bronchial epithelial cells. The boxes represent the interquartile range containing $50 \%$ of values. The bars extend to the highest and lowest values, excluding outliers, and the horizontal lines indicate the median values. $*$ : $p<0.05$ comparing TNF- $\alpha$-stimulated and unstimulated cells.

\section{IL-6 and IL-8 response was lower in cells from patients taking} inhaled corticosteroids.

It is interesting that in this study, both under baseline conditions and after TNF- $\alpha$ stimulation, lower absolute cytokine levels were detected from cells from COPD patients than from smokers with normal pulmonary function. This could be due to a defect in cytokine production by COPD HBEC in primary culture or a reflection of the situation in vivo. The explant cell culture technique developed in the laboratory is an established and validated method, which has
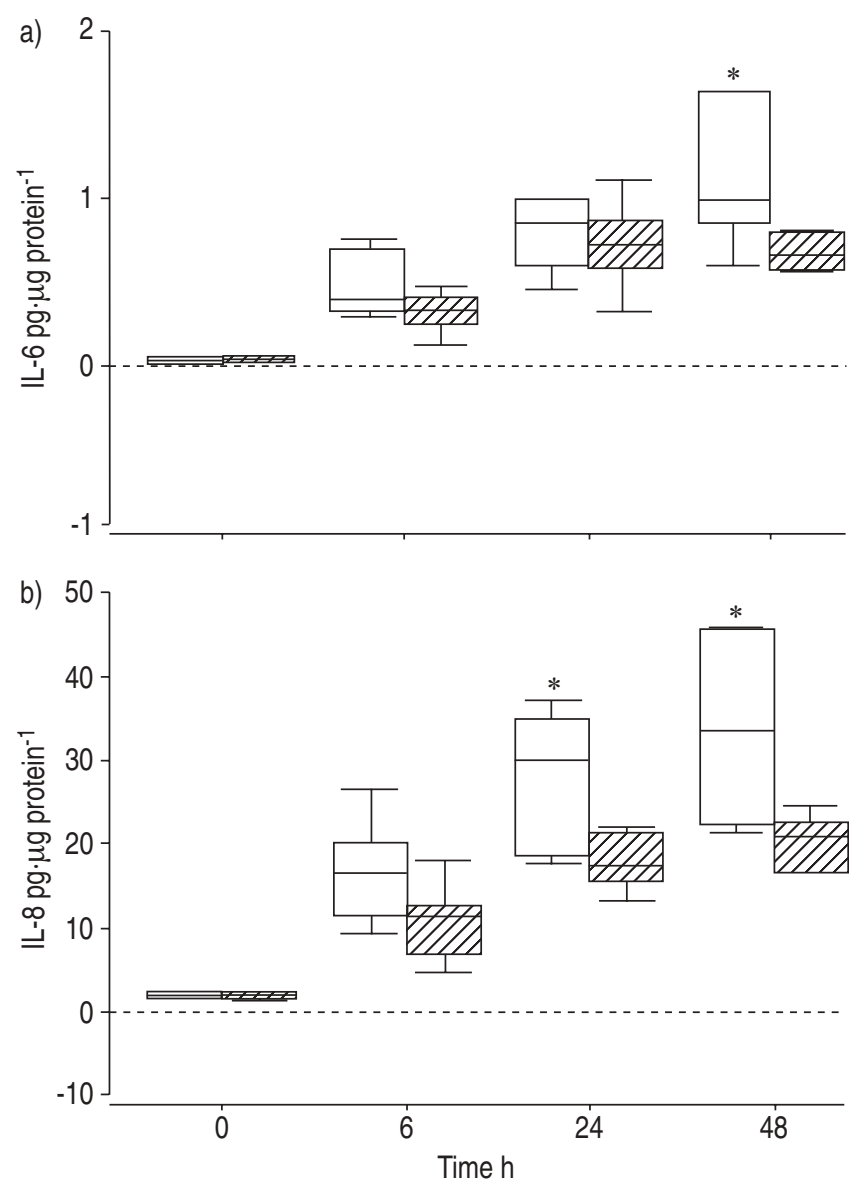

Fig. 2. - Production of a) interleukin (IL)-6 and b) IL-8 by tumour necrosis factor- $\alpha$-stimulated, primary-cultured chronic obstructive pulmonary disease bronchial epithelial cells in the presence $(\mathbb{Z})$ and absence $(\square)$ of regular, inhaled steroid therapy. The boxes represent the interquartile range containing $50 \%$ of values. The bars extend to the highest and lowest values, excluding outliers, and the horizontal lines indicate the median values. ${ }^{*}: \mathrm{p} \leqslant 0.05$.

previously been shown to allow the growth of welldifferentiated epithelial cells with similar morphological and biochemical characteristics to those found in vivo [17]. However, phenotypic differences between cells from COPD patients and those from normal subjects could have affected the results reported. Bronchial biopsies have shown epithelial shedding, reduced numbers of cilia [18] and a reduction in the proportion of ciliated cells [19] in chronic bronchitis and COPD. In a previous study of bronchial epithelial cells in culture, $10 \%$ of cells from smokers with normal lung function were reported to be ciliated, while those from patients with COPD were almost completely devoid of cilia [20]. While this was not found in the present study, disparities in the state of differentiation of the cell cultures may have accounted, in part, for the differences in levels of cytokine production by HBEC from COPD cells and those from current/exsmokers. This would need to be examined in similar studies.

There is also evidence to suggest that constitutive cytokine production by airway epithelial cells may be downregulated in COPD. ScHULz et al. [21] recently reported experimental results consistent with the present findings, with levels of constitutive IL-8 production from COPD epithelial cells in primary culture, which were approximately one-third of that seen from normal cells. It was postulated that this may be due to altered post-translational processing [21]. Factors may also exist in vivo that modulate airway inflammatory responses 
and that are absent in the sterile conditions of cell culture. The presence of colonising bacteria in the lower airway is increasingly recognised as an important independent stimulus to airway inflammation in COPD [22, 23]. The resultant recruitment of inflammatory cells [24], and interactions between bacterial and other cell products and the pulmonary epithelium $[25,26]$, may account for the increased levels of inflammatory cytokines isolated in sputum and bronchoalveolar lavage fluid in COPD, and for the downregulated epithelial inflammatory responses seen in this study under baseline conditions. Most studies of airway inflammation in COPD have been performed using sputum or bronchial biopsies and little information is available regarding whether airway epithelial activity in this condition reflects inflammation seen in other compartments. This requires further evaluation.

In the presence of an inflammatory stimulus like TNF- $\alpha$, a significant increase in cytokine production over constitutive release was seen in COPD epithelial cells, but not in those from current/exsmokers with normal pulmonary function. A recent study, comparing the effects of cigarette smoke, demonstrated a similar lack of cytokine production in primary-cultured epithelial cells from normal smokers, while cells from patients with COPD once again showed a significant response [20]. However, epithelial cells from normal subjects with normal lung function have previously been shown to produce good inflammatory cytokine responses to TNF- $\alpha$ [27]. These findings suggest that there may be important differences between the airway epithelium of smokers who do not develop COPD and those who do, with the former failing to mount a response to a common inflammatory stimulus. This could represent an important protective mechanism in smokers who do not develop COPD, possibly explained by differential expression of epithelial TNF- $\alpha$ receptors. These were not examined in the present study, and further studies of primary bronchial epithelial cells in well-characterised normal smokers and patients with COPD are now required.

The enhanced cytokine production by COPD cells following TNF- $\alpha$ stimulation may also be indicative of heightened airway inflammatory responses in this patient group. While not providing a complete model of COPD exacerbation, the response of the epithelium to a given inflammatory stimulus may be informative about general epithelial responses at COPD exacerbation. TNF- $\alpha$ is a ubiquitous cytokine that forms part of the final common pathway of a number of inflammatory processes in the airway. Upregulation of IL-6 and IL-8 production in response to this inflammatory stimulus could affect key inflammatory processes in the pathophysiology of COPD, including enhanced chemotaxis of inflammatory cells into the airway and upregulation of mucin genes. This response may therefore be a component of the mechanisms governing COPD exacerbation and could partly explain the tendency to exacerbation in this patient group.

It is interesting that in this study no significant sICAM-1 response was seen following $\mathrm{TNF}-\alpha$ stimulation, although previously TNF- $\alpha$ was shown to enhance epithelial expression of this molecule [28], which is upregulated in bronchial biopsies from patients with COPD [29]. These data therefore suggest that sICAM-1 production by epithelial cells in COPD may be dependent on a number of cofactors. ICAM-1 is the major receptor for human rhinovirus attachment on epithelial cells [30], and human rhinovirus has been shown to induce further ICAM-1 expression, thereby promoting inflammatory cell recruitment and activation as seen in exacerbations [31]. Airway epithelial cells play an important role in virus-induced inflammation [32] with viral infections, most commonly human rhinovirus, accounting for a significant proportion of COPD exacerbations [33,34]. A limitation of this cell culture model is that it did not take into account the crucial role of common viral triggers at COPD exacerbation and the epithelial response to them. An examination of the cellular pathways behind this finding may increase the understanding of the mechanisms of exacerbation in COPD.

A potentially important finding in this study was the attenuation of the IL- 6 and IL- 8 response to TNF- $\alpha$ seen in HBEC from COPD patients taking regular, inhaled steroid therapy. While in vitro evidence has demonstrated inhibitory effects of corticosteroids on IL-6 and IL-8 production in epithelial cell lines [35, 36], as well as on neutrophil chemotaxis [37] and airway neutrophilia [38], clinical studies of inhaled steroid therapy in COPD have largely shown this class of drugs to be of low efficacy. However, it was shown recently that inhaled corticosteroids may reduce the severity of COPD exacerbations [39]. On the basis of the current findings, the mechanism for this could be a reduction in exacerbation-associated inflammation. It has also been shown that inhaled steroids can reduce exacerbation frequency in COPD [40]. In this study, lower constitutive release of sICAM-1 was seen in cells from patients taking inhaled steroids. Therefore, it may be that inhaled steroids have a particular role in modifying virus-associated exacerbations, thereby reducing exacerbation frequency. Studies of steroid withdrawal in COPD have found a lag of several weeks between discontinuation of steroids and the next exacerbation [41], suggesting that the effects of corticosteroid therapy on mediator release, as seen in this study, are likely to have been the result of transcriptional alterations in cytokine production that persisted in vitro.

In summary, this study has demonstrated significant differences between primary airway epithelial cytokine production in patients with chronic obstructive pulmonary disease and smokers with normal pulmonary function, both constitutively and in response to an inflammatory stimulus. These observations may be important in distinguishing smokers who do not develop chronic obstructive pulmonary disease from those who do, as well as explaining the predisposition to exacerbation in this condition. The authors have also shown that epithelial inflammatory responses in chronic obstructive pulmonary disease can be modified by inhaled steroid therapy, which may partly explain the clinically observed effects of inhaled corticosteroids on chronic obstructive pulmonary disease exacerbations.

Acknowledgements. The authors would like to thank G. Berlyne and M. Beckles for assistance with obtaining the biopsy specimens.

\section{References}

1. Keatings VM, Barnes PJ. Comparison of inflammatory cytokines in chronic obstructive pulmonary disease, asthma and controls. Eur Respir Rev 1997; 7: 146-150.

2. Thompson AB, Daughton D, Robbins GA, Ghafouri MA, Oehlerking MA, Rennard SI. Intraluminal airway inflammation in chronic bronchitis. Characterization and correlation with clinical parameters. Am Rev Respir Dis 1989; 140: 1527-1537.

3. Saetta M, DiStefano A, Maestrelli $\mathrm{P}$, et al. Activated T-lymphocytes and macrophages in bronchial mucosa of subjects with chronic bronchitis. Am Rev Respir Dis 1993; 147: 301-306.

4. Osman LM, Godden DJ, Friend JAR, Legge SL, Douglas JG. Quality of life and hospital readmission in patients with chronic obstructive pulmonary disease. Thorax 1997; 52: 6771 . 
5. Seemungal TAR, Donaldson GC, Paul EA, Bestall JC, Jeffries DJ, Wedzicha JA. Effect of exacerbation on quality of life in patients with chronic obstructive pulmonary disease. Am J Respir Crit Care Med 1998; 157: 1418-1422.

6. Bhowmik A, Seemungal TAR, Sapsford RJ, Wedzicha JA. Relation of sputum inflammatory markers to symptoms and lung function changes in COPD exacerbations. Thorax 2000; 55: $114-120$.

7. Devalia JL, Davies RJ. Airway epithelial cells and mediators of inflammation. Respir Med 1993; 87: 405-408.

8. Marini M, Vittori E, Hollemborg J, Mottoli S. Expression of the potent inflammatory cytokines, granulocyte/macrophage colony-stimulating factor and interleukin-6, and interleukin8 , in bronchial epithelial cells of patients with asthma. J Allergy Clin Immunol 1992; 89: 1001-1009.

9. Devalia JL, Campbell AM, Sapsford RJ. Effect of nitrogen dioxide on the synthesis of inflammatory cytokines expressed by human bronchial epithelial cells in vitro. Am J Respir Cell Mol Biol 1993; 9: 271-278.

10. Abdelaziz MM, Devalia JL, Khair OA, Calderon M, Sapsford RJ, Davies RJ. The effect of conditioned medium from cultured human bronchial epithelial cells on eosinophil and neutrophil chemotaxis and adherence, in vitro. Am J Respir Cell Mol Biol 1995; 13: 728-737.

11. Keatings VM, Collins PJ, Scott DM, Barnes PJ. Differences in interleukin- 8 and tumour necrosis factor- $\alpha$ in induced sputum from patients with chronic obstructive pulmonary disease and asthma. Am J Respir Crit Care Med 1996; 153: $530-534$

12. Levine SJ. Bronchial epithelial cell-cytokine interactions in airway inflammation. J Invest Med 1995; 43: 241-249.

13. Pitkin AD, Roberts CM, Wedzicha JA. Arterialised blood gas analysis: an underused technique. Thorax 1994; 49: 364 366.

14. British Thoracic Society. Guidelines on diagnostic flexible bronchoscopy. Thorax 2001; 56: Suppl. 1, i1-i21.

15. Wang JH, Devalia JL, Sapsford RJ, Davies RJ. Effect of corticosteroids on release of RANTES and sICAM-1 from cultured human bronchial epithelial cells, induced by TNF- $\alpha$. Eur Respir J 1997; 10: 834-840.

16. Lowry ON, Rosebrough NJ, Farr AL, Randal RJ. Protein measurement with the folin phenol reagent. $J$ Biol Chem 1951; 193: 265-275.

17. Devalia JL, Sapsford RJ, Wells C, Richman P, Davies RJ. Culture and comparison of human bronchial and nasal epithelial cells in vitro. Respir Med 1990; 84: 303-312.

18. Ollerenshaw SL, Woolcock AJ. Characteristics of the inflammation in biopsies from large airways of subjects with asthma and subjects with chronic airflow limitation. $\mathrm{Am}$ Rev Respir Dis 1992; 145: 922-927.

19. Jeffery PK. Structural and inflammatory changes in COPD: a comparison with asthma. Thorax 1998; 53: 129-136.

20. Rusznak C, Mills PR, Devalia JL, Sapsford RJ, Davies RJ, Lozewicz S. Effect of cigarette smoke on the permeability and IL-1 $\beta$ and sICAM-1 release from cultured human bronchial epithelial cells of never-smokers, smokers, and patients with chronic obstructive pulmonary disease. Am J Respir Cell Mol Biol 2000; 23: 530-536.

21. Schulz C, Wolf C, Harth M, Riegger G, Pfeiffer M. Expression and release of interleukin- 8 from patients with COPD, smokers and healthy controls. Eur Respir J 2001; 18: Suppl. 33, 521s

22. Sethi S, Murphy TF. Bacterial infection in chronic obstructive pulmonary disease in 2000: a state-of-the-art review. Clin Microbiol Rev 2001; 14: 336-363.

23. Soler N, Ewig S, Torres A, Filella X, Gonzalez J, Zaubet A. Airway inflammation and bronchial microbial patterns in patients with stable chronic obstructive pulmonary disease. Eur Respir J 1999; 14: 1015-1022.

24. Ras G, Wilson R, Todd H, Taylor G, Cole P. Effect of bacterial products on neutrophil migration in vitro. Thorax 1990; 45: 276-280.

25. Khair OA, Devalia JL, Abdelaziz MM, Sapsford RJ, Tarraf $\mathrm{H}$, Davies RJ. Effect of Haemophilus influenzae endotoxin on the synthesis of IL-6, IL-8, TNF- $\alpha$ and expression of ICAM-1 in cultured human bronchial epithelial cells. Eur Respir $J$ 1994; 7: 2109-2116.

26. Amitani R, Wilson R, Rutman A, et al. Effects of human neutrophil elastase and Pseudomonas aeruginosa proteinases on human respiratory epithelium. Am J Respir Cell Mol Biol 1991; 4: 26-32.

27. Lordan JL, Bucchieri F, Richter A, et al. Cooperative effects of Th2 cytokines and allergen on normal and asthmatic bronchial epithelial cells. J Immunol 2002; 169: 407-414.

28. Rothlein R, Czajkowski M, O'Neill M, Mardlin SD, Mainolfi E, Merluzzi VJ. Induction of intercellular adhesion molecule 1 on primary and continuous lines by proinflammatory cytokines. J Immunol 1998; 141: 1665-1669.

29. Di Stefano A, Maestrelli P, Roggeri A, et al. Upregulation of adhesion molecules in the bronchial mucosa of subjects with chronic obstructive bronchitis. Am J Respir Crit Care Med 1994; 149: 803-810.

30. Staunton DE, Merluzzi VJ, Rothlein R, Barton R, Marlin $\mathrm{SD}$, Springer ST. A cell adhesion molecule, ICAM-1, is the major surface receptor for rhinoviruses. Cell 1989; 56: 849853.

31. Papi A, Johnston SL. Rhinovirus infection induces expression of its own receptor ICAM-1 via increased NF-kB mediated transcription. J Biol Chem 1999; 274: 9707-9720.

32. Subauste MC, Jacoby DB, Richards SM, Proud D. Infection of a human respiratory epithelial cell line with rhinovirus. $J$ Clin Invest 1995; 96: 549-557.

33. Seemungal TAR, Harper-Owen R, Bhowmik A, Jeffries DJ, Wedzicha JA. Detection of rhinovirus in induced sputum at exacerbation of chronic obstructive pulmonary disease. Eur Respir J 2000; 16: 677-683.

34. Seemungal TAR, Harper-Owen R, Bhowmik A, et al. Respiratory viruses, symptoms and inflammatory markers in acute exacerbations and stable chronic obstructive pulmonary disease. Am J Respir Crit Care Med 2001; 164: $1618-1623$.

35. Levine SJ, Larivee P, Logun C, William Angus C, Shelhamer JH. Corticosteroids differentially regulate secretion of IL-6, Il-8 and G-CSF by a human bronchial epithelial cell line. $\mathrm{Am}$ J Physiol 1993; 265: L360-L368.

36. Kwon OJ, Au BT, Collins PD, et al. Inhibition of interleukin-8 expression by dexamethasone in human cultured airway epithelial cells. Immunology 1994; 81: 389-394.

37. Llewewllyn-Jones CG, Harris TAJ, Stockley RA. Effect of fluticasone propionate on sputum of patients with chronic bronchitis and emphysema. Am J Respir Crit Care Med 1996; 153: 616-621.

38. Confalonieri M, Mainardi E, Della PR, et al. Inhaled corticosteroids reduce neutrophilic bronchial inflammation in patients with chronic obstructive pulmonary disease. Thorax 1998; 53: 583-585.

39. Paggiaro PL, Dahle R, Bakran I, Frith L, Hollingworth K, Efthimiou J. Multicentre randomised placebo-controlled trial of inhaled fluticasone propionate in patients with chronic obstructive pulmonary disease. Lancet 1998; 351: 773-780.

40. Burge PS, Calverley PMA, Jones PW, Spencer S, Anderson JA, Maslen TK. Randomised, double blind, placebocontrolled study of fluticasone propionate in patients with moderate to severe chronic obstructive pulmonary disease. BMJ 2000; 320: 1297-1303.

41. Jarad NA, Wedzicha JA, Burge PS, Calverley PM. An observational study of inhaled corticosteroid withdrawal in stable chronic obstructive pulmonary disease. ISOLDE study group. Respir Med 1999; 93: 161-166. 